\section{PHOSPHORYLATION AND INACTIVATION OF STREPTOMYCIN BY PLANT \\ PATHOGENIC PSEUDOMONAS LACHRYMANS}

Sir :

Inactivation of aminoglycoside antibiotics in clinical isolates has been studied by many research workers ${ }^{1}$. Streptomycin(SM)-inactivating enzymes were reported to exist in SM-resistant strains of Staphylococcus aureus ${ }^{2 \sim 4)}$, Escherichia coli $^{5 \sim 10)}$, and Pseudomonas aeruginosa ${ }^{11 \sim 13)}$, in which are operative 2 mechanisms, phosphorylation and adenylylation, i.e., SM 3"'-phosphotransferase; $\mathrm{APH}\left(3^{\prime \prime}\right)$, SM 6-phosphotransferase; APH(6), SM 3"-adenylyltransferase; AAD (3"), SM 6-adenylyltransferase; AAD(6). Pseudomonas lachrymans is known to be the cucumber angular leaf spot bacterium and SM-resistant strains have been recently isolated ${ }^{14)}$. However, the mechanisms of SM-resistance in plant pathogenic $P$. lachrymans have not been studied. Thirteen SM-resistant $P$. lachrymans were selected and biochemical mechanisms of SM-resistance in these strains were investigated.

Peptone water was used for liquid culture, which consisted of $10 \mathrm{~g}$ peptone, $5 \mathrm{~g} \mathrm{NaCl}$, and $1,000 \mathrm{ml}$ of deionized water. Bacteria were inoculated in peptone water and shaken at $27^{\circ} \mathrm{C}$. After 20 hours of incubation, cells were harvested. The S-30 fraction, the supernatant of $30,000 \mathrm{~g}$ centrifugation, was prepared as

Table 1. Inactivation of SM by SM-resistant $P$. lachrymans strains.

\begin{tabular}{c|r|c}
\hline $\begin{array}{c}\text { Bacterial } \\
\text { strains }\end{array}$ & $\begin{array}{c}\text { SM-resistance } \\
(\mu \mathrm{g} / \mathrm{ml})\end{array}$ & $\begin{array}{c}\text { Inactivation } \\
\text { of SM }\end{array}$ \\
\hline N-7401 & $>400$ & - \\
N-7403 & 100 & + \\
N-7504 & 200 & + \\
N-7506 & 200 & + \\
N-7513 & 200 & - \\
N-7554 & $>400$ & + \\
N-7582 & 50 & - \\
N-7585 & $>400$ & - \\
N-7588 & 50 & - \\
N-7590 & 50 & - \\
N-7595 & 100 & + \\
N-7598 & $>400$ & - \\
T-7445 & 12.5 & - \\
\hline
\end{tabular}

described in a previous paper ${ }^{33}$. An incubation reaction was carried out at $27^{\circ} \mathrm{C}$ for 1 hour and then stopped by heating in boiling water for 3 minutes. Antibiotic activity remaining in the reaction mixture was determined by bioassay using Bacillus subtilis ATCC6633 as test organism. As shown in Table 1, five P. lachrymans strains inactivated SM but the remaining 8 strains did not inactivate the drug under these conditions. The enzymatic transfer of the $\gamma /{ }^{32} \mathrm{P}$ or ${ }^{14} \mathrm{C}$-AMP from isotope-labeled ATP into $\mathrm{SM}$ was carried out as described previously ${ }^{3}$. From the result, we concluded that 5 strains inactivated SM by phosphorylation. $\gamma^{-32} \mathrm{P}-\mathrm{SM}$ was prepared by the inactivation reaction using the extract of one of the 5 strains N-7554. The reaction mixture contained: $100 \mu \mathrm{l}$ of S-30 fraction $(5 \mathrm{mg}$ of protein $/ \mathrm{ml}$ ), $20 \mu \mathrm{l}$ of $1 \mu \mathrm{Ci}$ of $\gamma /{ }^{32} \mathrm{P}$-ATP $(515 \mathrm{mCi} / \mathrm{mmol}), 20 \mu \mathrm{l}$ of $1 \mathrm{mM}$ of SM, $20 \mu 1$ of $0.02 \mathrm{M} \mathrm{MgCl}_{2}$, and $40 \mu 1$ of $0.2 \mathrm{M}$ tris- $\mathrm{HCl}$ buffer $(\mathrm{pH} \mathrm{7.0)}$. After 60 minutes of incubation at $27^{\circ} \mathrm{C}$, the reaction was stopped by heating in boiling water and centrifuged. The supernatant was pipetted onto a phosphocellulose paper and washed with deionized water, extracted with $10 \mathrm{ml}$ of $0.5 \mathrm{~N} \mathrm{HCl}$ and lyophilized. ${ }^{32} \mathrm{P}-$ labeled phosphoryl SM thus obtained, the authentic samples of SM-3" from $P$. aeruginosa TI-13 and SM-6-phosphate from $P$. aeruginosa GN573 were developed with the following solvent system on a thin-layer of silica gel (Tokyo Kasei). The radioactive spot of ${ }^{32} \mathrm{P}$-phosphoryl SM coincided exactly with the SAKAGUCHI reaction ${ }^{15)}$-positive spot of SM3"-phosphate (Rf 0.36), while Rf value of SM-6phosphate was 0.23 , on thin-layer chromatography using $\mathrm{CH}_{3} \mathrm{OH}-\mathrm{H}_{2} \mathrm{O}-15 \% \mathrm{NaCl}(9: 1: 5$ in volume). On high-voltage paper electrophoresis under 3,500 volts for 20 minutes using formic acid-acetic acid-water (25:75:900 in volume), the ${ }^{32}$ P-phosphoryl SM and SM-3"phosphate moved toward the cathode $9.4 \mathrm{~cm}$. From these results, it was concluded that the chemical structure of $\mathrm{SM}$ inactivated by $P$. lachrymans was SM-3"-phosphate. The biochemical mechanisms of SM resistance in the remaining 8 strains which could not inactivate the drug will be described elsewhere.

We are notified after submitting for publication that the same mechanism of SM resistance in $P$. lachrymans has been reported earlier by YANO et al. ${ }^{16)}$. 


\section{Acknowledgements}

We wish to thank Dr. A. OHuchr, National Institute of Agricultural Science, Tokyo, for providing bacterial cultures.

\section{HaRUHide KaWABE* \\ HiSASHI SAKURAI** \\ KeIJI Fukasawa \\ ShoJ SHIMIZU \\ KaTsumi Hasuda \\ SHIZUKO IYOBE \\ Susumu Mitsuhashi}

De sartment of Microbiology, School of Medicine, Gunma University, Maebashi *Episome Institute, Fujimi, Seta, Gunma

**Soil and Pesticide Section,

Environment Agency, Tokyo, Japan

(Received January 16, 1979)

\section{References}

1) Mitsuhashi, S.; S. Yamagishi, T. Sawai \& H. KAWAIBE: Biochemical mechanisms of plasmidmediated resistance. in $\mathrm{R}$ Factor-Drug Resistance Plasmid. pp. 195 251, Ed. by S. Mitsuhashi, University of Tokyo Press, Tokyo, 1977

2) Doi, O.; M. Miyamoto, N. Tanaka \& H. UMEZAWA: Inactivation and phosphorylation of kanamycin by drug-resistant Staphylococcus aureus. Appl. Microbiol. 16: $1282 \sim 1284,1968$

3) Kawaze, H.; M. Inoue \& S. Mitsuhashi: Inactivation of dihydrostreptomycin and spectinomycin by Staphylococcus aureus. Antimicr. Agents \& Chemoth. 5: 553 557, 1974

4) Suzuki, I.; N. Takahashi, S. Shirato, H. KaWABE \& S. Mitsuhashi: Adenylylation of streptomycin by Staphylococcus aureus: A new streptomycin adenylyltransferase. Microbial Drug Resistance. pp. 463 473, Ed. by S. MITSUHAishi \& H. Hashimoto, University of Tokyo Press, Tokyo, 1975

5) Benveniste, R.; Y. Yamada \& J. Davies: Enzymatic adenylylation of streptomycin and spectinomycin by R-factor-resistant Escherichia coli. Infect. Immunity 1: 109 119, 1970

6) Harwood, J. \& D. H. Smith: Resistance factor-mediated streptomycin resistance. J.
Bacteriol. 97: 1262 1271, 1969

7) Ozanne, B.; R. Benveniste, D. Tipper \& J. DAvies: Aminoglycoside antibiotics: Inactivation by phosphorylation in Escherichia coli carrying R factors. J. Bacteriol. 100: 1144 1146, 1969

8) Takasawa, S.; R. Utahara, M. Okanishi, K. Maeda \& H. Umezawa: Studies on adenylyl streptomycin, a product of streptomycin inactivation by $E$. coli carrying $\mathrm{R}$ factor. J. Antibiotics 21: 477 484, 1968

9) Umezawa, H.; S. Takasawa, M. OKanishi \& R. UTAHARA: Adenylylstreptomycin, a product of streptomycin inactivated by $E$. coli carrying R factor. J. Antibiotics 21: 81 82, 1968

10) Yamada, T.; D. Tipper \& J. Davies: Enzymatic inactivation of streptomycin by R-factor resistant Escherichia coli. Nature 219: 288 291, 1968

11) Doi, O.; M. Ogura, N. Tanaka \& H. UmeZAWA: Inactivation of kanamycin and streptomycin by enzymes obtained in cells of Pseudomonas aeruginosa. Appl. Microbiol. 16: $1276 \sim 1281,1968$

12) Kawabe, H.; F. Kobayashi, M. Yamaguchi, R. Utahara \& S. Mitsuhashi: 3"-Phosphoryldihydrostreptomycin produced by the inactivating enzyme of Pseudomonas aeruginosa. J. Antibiotics 24: 651 652, 1971

13) Kida, M.; T. Asako, M. Yoneda \& S. MitsuHASHI: Phosphorylation of dihydrostreptomycin by Pseudomonas aeruginosa. Microbial Drug Resistance. pp. $441 \sim 448, E d$. by S. MITSUHASHI \& H. HASHIMOTO, University of Tokyo Press, Tokyo, 1975

14) Hasuda, K. \& H. Sakurai: Drug-resistance of plant pathogenic Pseudomonas aeruginosa strains. Medicine and Biology (in Japanese) 95: $203 \sim 206,1977$

15) Sakaguchi, S.: Über eine neue Farbenreaktion von Protein und Arginin. J. Biochem. 5: $25 \sim 31,1925$

16) Yano, H.; H. Fujil, H. Mukoo, M. Shimura, T. Watanabe \& Y. Sekizawa: On the enzymatic inactivation of dihydrostreptomycin by Pseudomonas lachrymans, cucumber angular leaf spot bacterium: isolation and structural resolution of the inactivated product. Ann. Phytopath. Soc. (Japan) 44: 413 419, 1978 